\title{
MELTING ICE: A HOT TOPIC?
}

\author{
Sharadchandra P. Marahatta, MSc. AG, Ento ${ }^{17}$.
}

\begin{abstract}
A review of global melting ice and its causes as well as possible effects has been carried out based on available secondary information. Measured losses due to melting ice have been tabulated and in danger world heritage due to climatic changes were identified. Glaciers, marine bio-diversity, terrestrial biodiversity, archeological sites and historic cities were considered as the threat of melting ice and it is recommended to look for economic implications and technological options with other possible actions for tackling global warming.
\end{abstract}

Key words: bio-diversity, glaciers, global warming, melting ice, threat

\section{Introduction}

Ice contains large freshwater supplies and is an important part of the ecosystem. A rise in temperature leads to a reduction of ice and snow in mountain chains like the Himalayas of Asia and the Andes of Latin America. This changes the supply of freshwater via rivers, and affects agriculture, human health, plant and animal life in the areas which depend on this flow of freshwater from the mountains (World Environment Day, 2007). According to Environment News Service (2007), the international community now widely agrees that climate change will constitute one of the major challenges of the 21st century, which is directly related to melting of ice. Melting polar ice sheets contribute to a rise in sea level, which affects the people living on low islands and in low lying coastal areas. Numbers of climate refugees might reach enormous dimensions if millions of people in densely populated, low-lying countries are forced to move by rising sea levels. In the South Pacific, this has already begun to occur in some low-lying islands. Likewise, World watch Institute (2000) has mentioned 18 different locations from all around the world, where the threat of melting ice is alarming.

\section{Objectives}

The objectives of the paper are, to review the works related to global warming and melting ice and its effect in environment and to recommend required actions for managing global warming and melting ice.

\section{Methodology}

The findings of the paper are basically from the gleaning of secondary information published on journals, reports, monographs, articles and occasional publications. Group discussion among the co-workers and consultation of the information available in approachable libraries were also methods to get information for this paper.

\section{Melting ice and its global effect}

Accumulated worlds ice is melting in higher rates than our ordinary expectations. According to World watch Institute (2000) global ice melting accelerated during the 1990s-which was

\footnotetext{
${ }^{17}$ Seed Pathologist, Seed quality Control Centre, Harihar Bhawan. Email : sharadparasar@yahoo.com
} 
also the warmest decade on record. Measured losses due to melting ice in globally selected locations are presented in annex table 1.

Scientists suspect that the enhanced melting is among the first observable signs of humaninduced global warming, caused by the unprecedented release of carbon dioxide and other greenhouse gases over the past century (Hakala, 1998, World Watch Institute, 2000 and Albrecht and Kandji, 2003). Glaciers and other ice features are particularly sensitive to temperature shifts. Available facts tell that if global warming continues at its current pace, by 2100 Earth could be up to 8 degrees Fahrenheit warmer than it is today. If steps are not taken soon to reduce greenhouse emissions, the Arctic will be as warm as it was 130,000 years ago and similar rises in sea level will occur (Than, 2006).

Since 1979, the size of the summer polar ice cap has shrunk more than 20 percent and average temperatures in the Arctic region are rising twice as fast as they are elsewhere in the world (Natural Resources Defense Council, 2005). According to Brittrr (2006), all leading experts agree that the planet has warmed about 1 degree Fahrenheit in the past century. It is a well estimated that human-caused global warming will produce droughts and floods across the world that glaciers and ice sheets would melt, resulting in floods and rising sea levels as well as extreme weather events over the next century (Environment News Service. 2007). In addition to this, following world heritage are in danger due to melting of ice in an accelerated degree:

\section{Glaciers}

Coburn (2007), a mountain climber, hiked above the hamlet of Chukung, 11 miles south of Mount Everest, with Tenzing Sherpa, a former monk in the Tengboche monastery mentioned a glacier "Imja" in Mt. Everest belt. Now it became Imja Tsho (tsho is Tibetan for lake) with about a mile in length and up to 295 feet deep, which did not exist fifty years ago. The rapid melting and recession of the Imja Glacier, and the simultaneous growth of Imja Tsho, have alarmed national park staff and the Sherpas who grow potatoes and run trekking lodges in scattered villages down valley since 1994.

Environment News Service (2007) mentioned that the global average temperature increase projected by the end of the century ranges from 1.4 to 5.8 degrees $C$. At the same time, the UNESCO report stated that a 4 degree $C$ increase of atmospheric temperature would eliminate nearly all glaciers on Earth. This information knocks the danger for outstanding natural beauty of the all galleries including Nepal's Sagarmatha National Park, an exceptional Himalayan high altitude landscape dominated by Mount Everest, the world's highest mountain as well as rare wildlife species such as the snow leopard and the red panda. It is difficult to predict disastrous effects on human lives with flooding resulting from glacial lake outbursts threatening human settlements, which is not very far from today.

\section{Marine Biodiversity}

Recently, melting ice in Antarctica has discovered several previously unknown species of marine life, including deep sea lilies, gelatinous sea squirts, glass sponges, amphipod crustaceans, and orange starfish (Mongabay.com, 2007). Due to the global warming, now it is possible to make a unique inventory of life forms on a part of the seabed that had been sealed off for thousands of years by massive ice shelves before they suddenly broke up (The Independent, 2007). Opposite to above, it is expected that seventy percent of the world's deep sea corals, inhabited by hundreds of thousands of fish species, will be affected by changing conditions related to rising temperatures and increased ocean acidification by the year 2100 . At present, coral reefs provide livelihoods to 100 million people and provide the 
basis for industries such as tourism and fishing, worth an annual net benefit of US $\$ 30$ billion. Changing marine bio-diversity will be a calamity for those people and industries (Environment News Service, 2007). According to Department of Environment and Heritage, Government of South Australia (2006), global warming - caused by industrial and consumer activities which emit carbon dioxide and other greenhouse gases into the atmosphere is a major cause of changing marine bio-diversity. Melting ice causes sea level rise, which can reduce the habitat of inertial species and modify oceanographic conditions

\section{Terrestrial Biodiversity}

Biodiversity on land is also threatened by climate change. It is determined that warming confuses migratory pattern of many species like bats, turtles etc. It creates early hatching in butterflies, accelerates evolution of weeds, changes in seasons, accelerates extinction of species, rises polar bear mortality, creates earlier laying of eggs in turtle, enhances extinction of monarch butterflies, alternates in squirrel's reproduction, initiates genetic change in mosquitoes, declines frogs population, and ultimately disrupts whole ecosystem (The heat is online, 2007). As an example, Cape Floral Region, the richest area for plants in the world, which lies in the Africa, is in a great danger due to the change in terrestrial biodiversity. It is estimated that four out of five protected areas in South Africa are predicted to lose 10 percent to 40 percent of their plant species by the year 2050 (Environment News Service, 2007).

\section{Archaeological Sites}

Chan Chan Archaeological Zone, Peru, alongside other properties in Canada and the Russian Federation are archaeological World Heritage sites and in a threat of damage due to change in climate (Environment News Service, 2007).

\section{Historic Cities}

Over the past century, sea level over much of the United States has risen by 25 to 30 centimeters relative to land (The why files, 1999), which alarms for the protection of many historic cities.

Climate changes probably bring a devastating effect on both the buildings and social fabric of historic cities and settlements through rising sea levels and flooding. River Thames which flows through the City of London is a typical example of having a threat for this ancient city. It is estimated that by 2100 , the Thames Barrier will need to be closed about 200 times per year to protect London from tidal flooding. Like wise, other historic cities as Venice, Prague, Timbuktu etc. are also threatened by flooding (Environment News Service, 2007).

\section{Conclusion and Recommendations}

UN has already declared that the world has only eight years left to save climate (Climate Today, May 8, 2007; available at: http://climatetoday.org/?p=147 ), which indicates the threat of melting ice and global warming. Hence, following points are recommended to fight against this global challenge and improve the situation:

- Looking for economic implications and technological options for tackling global warming.

- Implementing polluters pay principle and creating a global fund for research and studies. More funds have to collect from the countries having higher degree of emissions of greenhouse gases.

- Encourage for "carbon cut" and "UV light reduction" global policy. 


\section{Annex}

Table 1 Selected examples of ice melt around the world

\begin{tabular}{|c|c|c|}
\hline Name & Location & Measured loss \\
\hline $\begin{array}{l}\text { Arctic } \\
\text { Sea Ice }\end{array}$ & Arctic Ocean & $\begin{array}{l}\text { Has shrunk by } 6 \text { percent since } 1978 \text {, with a } 14 \text { percent loss of } \\
\text { thicker, year-round ice. Has thinned by } 40 \text { percent in less than } 30 \\
\text { years. }\end{array}$ \\
\hline $\begin{array}{l}\text { Greenland } \\
\text { Ice Sheet }\end{array}$ & Greenland & $\begin{array}{l}\text { Has thinned by more than a meter a year on its southern and } \\
\text { eastern edges since } 1993 \text {. }\end{array}$ \\
\hline $\begin{array}{l}\text { Columbia } \\
\text { Glacier }\end{array}$ & $\begin{array}{l}\text { Alaska, } \\
\text { United } \\
\text { States }\end{array}$ & $\begin{array}{l}\text { Has retreated nearly } 13 \text { kilometers since } 1982 \text {. In } 1999 \text {, retreat rate } \\
\text { increased from } 25 \text { meters per day to } 35 \text { meters per day. }\end{array}$ \\
\hline $\begin{array}{l}\text { Glacier, } \\
\text { National Park }\end{array}$ & $\begin{array}{l}\text { Rocky Mtns., } \\
\text { United } \\
\text { States }\end{array}$ & $\begin{array}{l}\text { Since } 1850 \text {, the number of glaciers has dropped from } 150 \text { to fewer } \\
\text { than } 50 . \text { Remaining glaciers could disappear completely in } 30 \text { years. }\end{array}$ \\
\hline $\begin{array}{l}\text { Antarctic } \\
\text { Sea Ice }\end{array}$ & $\begin{array}{l}\text { Southern } \\
\text { Ocean }\end{array}$ & $\begin{array}{l}\text { Ice to the west of the Antarctic Peninsula decreased by some } 20 \\
\text { percent between } 1973 \text { and 1993, and continues to decline. }\end{array}$ \\
\hline $\begin{array}{l}\text { Pine Island } \\
\text { Glacier }\end{array}$ & $\begin{array}{l}\text { West } \\
\text { Antarctica }\end{array}$ & $\begin{array}{l}\text { Grounding line (where glacier hits ocean and floats) retreated } 1.2 \\
\text { kilometers a year between } 1992 \text { and } 1996 \text {. Ice thinned at a rate of } \\
3.5 \text { meters per year. }\end{array}$ \\
\hline $\begin{array}{l}\text { Larsen B } \\
\text { Ice Shelf }\end{array}$ & $\begin{array}{l}\text { Antarctic } \\
\text { Peninsula }\end{array}$ & $\begin{array}{l}\text { Calved a } 200 \mathrm{~km} 2 \text { iceberg in early } 1998 \text {. Lost an additional } 1,714 \\
\mathrm{~km} 2 \text { during the } 1998-1999 \text { seasons and } 300 \mathrm{~km} 2 \text { so far during the } \\
1999-2000 \text { seasons. }\end{array}$ \\
\hline $\begin{array}{l}\text { Tasman } \\
\text { Glacier }\end{array}$ & New Zealand & $\begin{array}{l}\text { Terminus has retreated } 3 \text { kilometers since } 1971 \text {, and main front has } \\
\text { retreated } 1.5 \text { kilometers since } 1982 \text {. Has thinned by up to } 200 \\
\text { meters on average since the } 1971-82 \text { periods. Icebergs began to } \\
\text { break off in } 1991 \text {, accelerating the collapse. }\end{array}$ \\
\hline $\begin{array}{l}\text { Meren, } \\
\text { Carstenz, and } \\
\text { Northwall Firn } \\
\text { Glaciers }\end{array}$ & $\begin{array}{l}\text { Irian Jaya, } \\
\text { Indonesia }\end{array}$ & $\begin{array}{l}\text { Rate of retreat increased to } 45 \text { meters a year in 1995, up from only } \\
30 \text { meters a year in 1936. Glacial area shrank by some } 84 \text { percent } \\
\text { between } 1936 \text { and 1995. Meren Glacier is now close to disappearing } \\
\text { altogether. }\end{array}$ \\
\hline $\begin{array}{l}\text { Dokriani } \\
\text { Bamak Glacier }\end{array}$ & $\begin{array}{l}\text { Himalayas, } \\
\text { India }\end{array}$ & $\begin{array}{l}\text { Retreated by } 20 \text { meters in 1998, compared with an average retreat } \\
\text { of } 16.5 \text { meters over the previous } 5 \text { years. }\end{array}$ \\
\hline $\begin{array}{l}\text { Duosuogang } \\
\text { Peak }\end{array}$ & $\begin{array}{l}\text { Ulan Ula } \\
\text { Mtns., China }\end{array}$ & Glaciers have shrunk by some 60 percent since the early 1970 s. \\
\hline $\begin{array}{l}\text { Tien Shan } \\
\text { Mountains }\end{array}$ & Central Asia & $\begin{array}{l}\text { Twenty-two percent of glacial ice volume has disappeared in the } \\
\text { past } 40 \text { years. }\end{array}$ \\
\hline Caucasus & Russia & Glacial volume has declined by 50 percent in the past century. \\
\hline Alps & $\begin{array}{l}\text { Western } \\
\text { Europe }\end{array}$ & $\begin{array}{l}\text { Glacial area has shrunk by } 35 \text { to } 40 \text { percent and volume has } \\
\text { declined by more than } 50 \text { percent since } 1850 \text {. Glaciers could be } \\
\text { reduced to only a small fraction of their present mass within } \\
\text { decades. }\end{array}$ \\
\hline Mt. Kenya & Kenya & Largest glacier has lost 92 percent of its mass since the late 1800 s. \\
\hline
\end{tabular}




\begin{tabular}{|l|l|l|}
\hline Speka Glacier & Uganda & $\begin{array}{l}\text { Retreated by more than } 150 \text { meters between } 1977 \text { and } 1990, \\
\text { compared with only 35-45 meters between } 1958 \text { and } 1977 .\end{array}$ \\
\hline Upsala Glacier & Argentina & $\begin{array}{l}\text { Has retreated } 60 \text { meters a year on average over the last } 60 \text { years, } \\
\text { and rate is accelerating. }\end{array}$ \\
\hline $\begin{array}{l}\text { Quelccaya } \\
\text { Glacier }\end{array}$ & Andes, Peru & $\begin{array}{l}\text { Rate of retreat increased to } 30 \text { meters a year in the 1990s, up from } \\
\text { only 3 meters a year between the 1970s and } 1990 .\end{array}$ \\
\hline
\end{tabular}

Source: (World Watch Institute, 2000)

\section{REFERENCES}

1. Albrecht, A. and S.T. Kandji. 2003: Carbon sequestration in tropical agroforestry systems. Agriculture, Ecosystems \& Environment, 99(1/3):15-27.

2. Brittrr, R.R. 2006: Conflicting Claims on Global Warming and Why It's All Moot. LiveSciences. Available at http://www.livescience.com/environment/060201_temperature_differences.html

3. Coburn, B. 2007: Himalaya Melting. On earth. Natural Resources Defense Council (NRDC). Available at: http://www.nrdc.org/OnEarth/07win/himalaya1.asp

4. Department of Environment and Heritage, Government of South Australia. 2006: Marine Biodiversity. Posted on September 4, 2006. Available at: http://www.environment.sa.gov.au/coasts/mpas/background/marine_biodiversity.h tml

5. Environment News Service. 2007: UNESCO World Heritage Sites in Danger of Global Warming; posted on April 10, 2007. Available at: http://www.ensnewswire.com/ens/apr2007/2007-04-10-

6. Hakala, K. 1998: Growth and yield potential of spring wheat in a simulated changed climate with increased $\mathrm{CO}<\mathrm{sub}(2)>$ and higher temperature. European Journal of Agronomy, 9(1):41-52.

7. Mongabay.com. 2007: Melting ice reveals unknown species in Antarctica. Posted on February 26, 2007. Availabe at: http://news.mongabay.com/2007/0226-coml.html

8. Natural Resources Defense Council (NRDC). 2005: Global Warming Puts the Arctic on Thin Ice. Available at: http://www.nrdc.org/globalwarming/qthinice.asp

9. Than, K. 2006: Polar Meltdown Near: Seas Could Rise 3 Feet Per Century. LiveSciences. Available at: http://www.livescience.com/environment/060323_ice_melt.html

10. The heat is online. 2007: Available at: http://www.heatisonline.org/migrations.cfm

11. The Independent. 2007: Melting ice gives birth to a strange new world. Posted on

February 26, 2007.Availableat:

http://news.independent.co.uk/environment/climate_change/article2305512.ece

12. The why files. 1999. Beach Erosion. Available at:

http://whyfiles.org/091beach/5.html

13. World Environment Day. 2007: Melting ice - a hot topic? Posted on March 29, 2007. Availableat:http://www.wed.npolar.no/world-environment-day2007/view?set_language $=e n$

14. World watch Institute. 2000: Melting of Earth's Ice Cover Reaches New High. Posted on March 6. Available at: http://www.worldwatch.org/node/1673 